University of Wollongong

Research Online

Faculty of Social Sciences - Papers (Archive) Faculty of Arts, Social Sciences \& Humanities

$1-1-2017$

Inspiring environmentally responsible preschool children through the implementation of the National Quality Framework: Uncovering what lies between theory and practice

Krista Pollock

University of Wollongong

Jane D. Warren

University of Wollongong, jwarren@uow.edu.au

Peter J. Andersen

University of Wollongong, petera@uow.edu.au

Follow this and additional works at: https://ro.uow.edu.au/sspapers

Part of the Education Commons, and the Social and Behavioral Sciences Commons

Research Online is the open access institutional repository for the University of Wollongong. For further information contact the UOW Library: research-pubs@uow.edu.au 


\title{
Inspiring environmentally responsible preschool children through the implementation of the National Quality Framework: Uncovering what lies between theory and practice
}

\author{
Abstract \\ EARLY CHILDHOOD EDUCATION FOR environmental sustainability (ECEfES) has become significant in the \\ early years, as highlighted by the inclusion of ECEfES in Australia's first and current National Quality \\ Framework (NQF) for early childhood education and care (ECEC). This article reports on the major \\ findings from a case study (Pollock, 2014), which aimed to uncover what lies between theory and \\ practice, as ECEC educators attempt to support young children to become environmentally responsible, \\ through the implementation of the NQF. This article discusses some of the findings from an analysis of \\ the documents central to the NQF as well as semi-structured interviews with three university-qualified \\ educators. Thematic analysis revealed that although challenging educators in some respects, the \\ introduction of the NQF has enhanced their sustainability practices. This has emphasised the importance \\ of listening to the voices of young children, a 'whole of settings' approach, and engaging in reflection.

\section{Keywords} \\ environmentally, responsible, preschool, children, implementation, uncovering, inspiring, practice, lies, \\ theory, between, national, quality, framework: \\ Disciplines \\ Education | Social and Behavioral Sciences \\ Publication Details \\ Pollock, K., Warren, J. D. \& Andersen, P. J. (2017). Inspiring environmentally responsible preschool \\ children through the implementation of the National Quality Framework: Uncovering what lies between \\ theory and practice. Australasian Journal of Early Childhood, 42 (2), 12-19.
}




\title{
Inspiring environmentally responsible preschool children through the implementation of the National Quality Framework: Uncovering what lies between theory and practice
}

http://dx.doi.org/10.23965/AJEC.42.2.02

\author{
Krista Pollock \\ Jane Warren \\ Peter Andersen \\ University of Wollongong
}

\begin{abstract}
EARLY CHILDHOOD EDUCATION FOR environmental sustainability (ECEfES) has become significant in the early years, as highlighted by the inclusion of ECEfES in Australia's first and current National Quality Framework (NOF) for early childhood education and care (ECEC). This article reports on the major findings from a case study (Pollock, 2014), which aimed to uncover what lies between theory and practice, as ECEC educators attempt to support young children to become environmentally responsible, through the implementation of the NOF. This article discusses some of the findings from an analysis of the documents central to the NOF as well as semi-structured interviews with three university-qualified educators. Thematic analysis revealed that although challenging educators in some respects, the introduction of the NQF has enhanced their sustainability practices. This has emphasised the importance of listening to the voices of young children, a 'whole of settings' approach, and engaging in reflection.
\end{abstract}

\section{Introduction and background to this study}

Today's children are born into a world where there are serious concerns for the sustainability of our planet. Given the plight of the environment there has been an increase in calls for action, globally and locally, for a more sustainable future (Commonwealth of Australia Department of Climate Change and Energy Efficiency, 2011; United Nations Environment Program, 2015). Early childhood education for sustainability (ECEfS) has been nationally and globally recognised as having the potential to nurture caring, capable and responsible citizens, by providing children with knowledge about sustainability problems, a voice in decision-making about these issues and the skills to do something about it (Davis \& Elliott, 2014; Pramling Samuelsson \& Kaga, 2008).

ECEfS can be defined in terms of its three interdependent pillars of sustainability-economic, social and cultural, and environmental (Green, 2013). Early childhood education for environmental sustainability (ECEfES) focuses on the disadvantages caused by humans' unsustainable treatment of the earth. ECEfES considers: the drawbacks of depleting natural resources, overflowing landfills, increased greenhouse gas emissions, rising sea levels and polluted waterways, focusing on how the poorest countries are the worst affected by these challenges in terms of poverty, migration, food and water scarcity, and health care problems (Siraj-Blatchford, Smith \& Pramling Samuelsson, 2010).

Evidently, ECEfS is multifaceted and each area is interrelated and interdependent. Introducing children to explicit ideas about this harmonious and interdependent relationship at a young age can lead to responsible stewardship (Chan, Choy \& Lee, 2009), highlighting the need for active provision of quality ECEfES.

Research is emerging that focuses on successful ECEfES pedagogies taking into account sociocultural contexts of children, particularly the crucial role of families and their influence in shaping children's values, behaviours, attitudes, skills and habits (Pramling Samuelsson \& Kaga, 2008). Successful ECEfES programs engage whole communities, focus on individual's strengths and contributions, and are contextually relevant to the community of the early childhood education and care (ECEC) centre-leading to a permeation of sustainable behaviours within the community (Cutter-Mackenzie \& Edwards, 2006; Davis, 2005, 2008; Ritchie, Duhn, Rau \& Craw, 2010; UNESCO, 2012). 
There is substantial research demonstrating the undeniable benefits of quality ECEC for children, families and communities, recognising ECEC as a crucial vehicle for lifelong ECEfES learning (Davis et al., 2009; Tilbury, 2013). Chawla and Cushing (2007) revealed a conclusive relationship between positive early childhood experiences in nature and the formation of pro-environment beliefs and behaviours later in life. In fact, ECEfES can be a transformative and empowering process for children (Davis \& Elliott, 2014; Vaealiki \& Mackey, 2008), and by using a combination of age appropriate pedagogical approaches, young children have been found to be capable of engaging in sophisticated thinking about complex environmental issues (Edwards \& Cutter-Mackenzie, 2011; Palmer \& Suggate, 2004). As children realise their ideas, knowledge and opinions are associated with real change, children feel empowered and learning results in meaningful engagement (Ji \& Stuhmcke, 2014; Lewis, Mansfield \& Baudains, 2010). ECEfES provides vital steps towards creating environmentally conscious communities in the future. While the ECEC sector is starting to recognise the relevance of ECEfES to young children (Pramling Samuelsson \& Kaga, 2008), scholarly research reflecting specific approaches and practices of ECEfES is needed (Davis \& Elliott, 2014).

Notably, research shows a lack of engagement with ECEfES. Too frequently, ECEC educators misinterpret the point of ECEfES, thinking it is only about outdoor play in nature and disregarding the need to explore underlying themes of sustainability (Elliott, 2014; Elliott \& Davis, 2009; Elliott \& Young, 2016; Inoue, O'Gorman \& Davis, 2016). Many ECEC educators are unaware of, or overwhelmed by sustainability issues; and their own environmental education during their formative and school years was lacking, causing their teachings to be incomplete and short term (Domka, 2004; Dymenta et al., 2014; Ritchie, Duhn, Rau \& Craw, 2010). Educators cite they simply do not have enough time (Davis, 2008; Salonen \& Tast, 2013) and lack engagement from busy families who feel that time spent talking about sustainability issues would be better spent focusing on other, 'more academic' subjects (Ritchie et al., 2010). The delayed inclusion of ECEfES in ECEC can be attributed to the misconception that the abstract concepts within ECEfES are beyond the cognitive grasp of young children, or that children are vulnerable and immature, untouched by depressing events around them (Bentley, 2013; Davis et al., 2009; Pramling Samuelsson, 2011). This idea that children are not capable of engaging with ECEfES is a result of out-dated paradigms that do not reflect current pedagogical thinking (Elliott \& Davis, 2009) and pre-date the United Nations (UN) Convention on the Rights of the Child (UNICEF, 1989).

As soon as we recognise that the world population group with the greatest stake in the future are children, that it is their future that depends upon it, then the matter becomes a citizenship issue and a question of rights (Siraj-Blatchford, 2009, p. 9).
Significantly, in Australia in 2012, the National Quality Framework (NOF) was introduced. Two key components of the NQF-the National Quality Standard (NQS) and the Early Years Learning Framework (EYLF)_present numerous expectations of educators, and centres are rated in terms of their quality in seven key areas of the NOS (ACECQA, 2013; DEEWR, 2009). A number of EYLF outcomes and NQS quality areas relate directly to ECEfES and acknowledge its important role. While some ECEfES intentions are explicit, further analysis of the documents could expose greater detail and perhaps less explicit ECEfES outcomes. Both the NQS and the EYLF place the onus on ECEC educators to implement ECEfES in their centres. However, there is a distinct lack of research that is designed to better understand the challenges facing Australian ECEC educators as they attempt to implement these requirements-more needs to be known about the relationships between the theory behind these components of the NQF and the reality of life 'on the ground' for the educators, children and families in these centres.

Great responsibility is on the shoulders of Australian ECEC educators to give young children a voice in creating a more sustainable future. With a limited research base to inform them and an absence of government-sponsored resources, it is a challenge for ECEC educators to implement quality ECEfES programs that align with the sustainability outcomes and quality areas interspersed throughout the NQS and EYLF. This current study sought to understand how the NOS and EYLF have assisted ECEC educators in supporting children to become environmentally responsible; and to examine the lessons learnt by these educators as they undertook this complex task.

\section{This study}

This study was a qualitative case study that focused on the experiences of three educators as they attempted to implement the NOF and support children to become environmentally responsible. The study took place in their Illawarra, New South Wales (NSW) ECEC centre, during 2014, for an Honours project and was guided by the central research question: 'How has the NQF assisted ECEC educators in supporting children to become environmentally responsible?' The following sections describe the theoretical framework and research design, the participants, data collection and analysis procedures, findings and how the findings contribute to improving knowledge and understanding around ECEfES in ECEC settings.

\section{Theoretical framework and research design}

The research design was framed by sociocultural theory, which is based on the work of Vygotsky (1978). Vygotsky's sociocultural theory examines the role and effect of social and cultural contexts on children's learning and 
development (Edwards, 2009). Within sociocultural theory, children's knowledge construction is recognised as an active process of exploration of their environment, as well as collaboration and interaction between children, their families, educators and the community (CutterMackenzie \& Edwards, 2006). ECEC settings are places in which children have opportunities to actively explore their environment, while collaborating and interacting with their educators and peers.

Crucially, sociocultural theory encourages educators to acknowledge and develop children's prior socio-culturally constructed knowledge, while exploring alternative paradigms for understanding children (Fleer \& Richardson, 2004). One such paradigm is the preconception that children are capable and resourceful beings, and active agents of change within ECEfES (Davis \& Elliot, 2014). Sociocultural theory emphasises the active role that educators play in supporting environmentally responsible behaviour in children. ECEC settings are suitable research sites that take into account the familial, educational and social forces that influence the interactions between educators and children.

As this study concentrated on the experience of educators in the ECEC sector, qualitative data was required to achieve a holistic and accurate representation of their experiences. Qualitative case studies have a long history as intensive studies that produce rich descriptions of a single phenomenon, event, organisation, or program (Stake, 1995; Yin, 1984). A single instrumental case study (Stake, 1995) involving a small group of preschool educators was ideal for developing a focused collection of detailed responses that were specific to the preschool's context.

The NQS and EYLF were analysed because of their importance in the ECEC sector, and the sociocultural theory that underpins their content (ACECQA, 2013; Edwards, Fleer \& Nuttall, 2008). At the heart of each document is the notion that interactions with others play a pivotal role in children's learning. Children's knowledge is highly valued and respectful relationships between children, educators, families and the community are essential for children to engage in sustained, meaningful learning. While the sociocultural underpinnings of these documents place value on children's expertise and contributions, children were not a direct part of this research study and did not contribute to the data directly. The data acquired from educators, however, was analysed through a sociocultural lens.

\section{Participants}

The site was a well-established preschool in the Illawarra region of NSW. The researcher had an existing relationship with the preschool through participation in the University of Wollongong Early Years Mentoring Program. The site was chosen purposefully because of demonstrated ECEfES practice. Three university-qualified early childhood teachers working within the 40-place centre participated in this study.
Two of these educators (Ashley and Charlotte) had been at the centre for 20 years, and the third educator (Denise) for a period of three years. These educators worked across the two rooms in the centre. Prior to the commencement of the research, ethics approval was granted by the University of Wollongong Human Research Ethics Committee (HE14/022). Participants were informed their participation was voluntary. Respect for their experiences and knowledge was a principal ethical consideration.

\section{Data collection}

Data collection methods for this study included document analysis of the key components within the NQF: The EYLF (DEEWR, 2009) and the Guide to the National Quality Standard (ACECQA, 2013), as these documents ultimately govern and guide the practices of ECEC educators. Compatible with the nature of qualitative research, document analysis is a systematic process for examining or reviewing information within documents (Bowen, 2009). The document analysis was driven by the supporting research question: What are the expectations of the documents within the NQF in relation to ECEfES?

The second phase of data collection included individual audio-recorded, semi-structured interviews with the three university-qualified educators. Guiding questions (informed by the document analysis) explored the educators' perceptions and experiences of ECEfES since the introduction of the NQF. The interviews answered two supporting research questions:

What are educators doing to meet the requirements of the documents within the NQF in relation to ECEfES?

To what degree have the expectations of the documents within the NQF assisted educators to support young children to become environmentally responsible?

Interviews were 30 minutes in duration and were transcribed by the researcher. Following the transcription process an additional five-minute interview was scheduled for one of the participants to elicit further detail regarding some experiences discussed in the previous interviews. This added depth to the educator's prior responses and contributed significantly to the findings.

\section{Data analysis}

Data analysis involved thematic analysis-a flexible and useful research tool for identifying, analysing and reporting patterns, or themes that provide a detailed and complex account of the data (Braun \& Clarke, 2006). As anticipated, the document analysis and interviews produced common themes that extended across multiple interviews, as well as the document analysis. 
Initially, particular trends and links were identified throughout the interviews and NOF documents and selections of relevant text were clustered. These clusters were later systematically analysed for repeating concepts and ideas that were evident in response to the supporting research questions. In order to ensure clear organisation of themes and subthemes, key phrases from the document analysis and transcribed interviews were clustered into codes, allowing the researcher to identify their frequency and relevance.

\section{Findings and discussion}

The findings of this study highlighted significant themes, relating to core practices and approaches prioritised by the educators. The findings showed that the implementation of the NQF was necessary, but challenging for the educators. They also highlighted that the educators were strongly aware of the importance of giving children a 'voice' in ECEfES programs; the NQF provided the educators with guidance around the importance of a 'whole of settings' approach for embedding ECEfES; and that the NQF provided the educators with a means of reflecting on their ECEfES practices.

\section{The NOF: Necessary and challenging}

The educators in this study revealed that tension can exist as educators attempt to balance their recognition of the urgency of the environmental crisis and the mounting pressures to meet the various requirements within the NQF. The educators felt strongly that ECEfES is of great necessity and the inclusion of ECEfES-related outcomes in the NQF is justified. It was clear the educators in this study viewed ECEC as having a significant role in developing life-long pro-environmental attitudes, behaviours and skills, which supports research with similar findings (Pramling Samuelsson \& Kaga, 2008).

The findings from the document analysis highlighted considerable ECEfES related expectations that were not present within the previous guiding framework, the NSW Curriculum Framework (Stonehouse, 2002). The EYLF and NQS were analysed and revealed key themes: references to ECEfES; providing natural spaces and resources; contributing to a sustainable future; embedding sustainable practices; supporting children to become socially and environmentally responsible; meeting required expectations; and fexibility within documents (ACECQA, 2011; 2013; DEEWR, 2009). Each of these themes were addressed, providing a support to the more significant participant interviews. The documents refer to ECEfES in varying degrees. Within the NOS, the standard that focuses primarily on ECEfES is Standard 3.3: 'The service takes an active role in caring for its environment and contributes to a sustainable future' (ACECQA, 2013, p. 99). The outcome that relates most obviously to ECEfES is Outcome 2 of the EYLF: 'Children are connected with and contribute to their world' (DEEWR, 2009, p. 25).
Concisely, some responsibilities include providing natural spaces and resources for children to foster awareness of the interdependence between people, animals, plants and the land, as well as developing policies and practices that contribute to a sustainable future (ACECQA, 2013; DEEWR, 2009). In order to achieve a quality rating, ECEC educators need to be meeting the ECEfES requirements, as well as attending to the numerous other expectations. For example, centres must develop a Quality Improvement Plan (QIP) that encompasses the numerous goals they will work towards to be meeting the NOS (ACECQA, 2013).

For the educators in this study, implementing the ECEfES requirements of the NOF was an evolving process, rather than a sudden change. The centre focused on ECEfES before the introduction of the NOF. Denise recalled past memories, where they implemented sustainable practices such as 'reduce, reuse, recycle ... But not on the same level as we are now'. The NOF prompted the educators to think about ECEfES on a whole new level, engaging educators in a process that increased their awareness, improved their practices and built on their commitment in a very practical way. This is reflective of research exploring sustainability as an embedded culture, exemplifying that this process does not happen overnight and has its challenges (Davis, 2005; Elliott, 2014; Ji \& Stuhmcke, 2014; Reunamo, 2007; Ritchie, Duhn, Rau \& Craw, 2010; Stuhmcke, 2012; UNESCO, 2012).

While the educators felt they were meeting the ECEfES requirements, they identified challenges that hindered progress, aligning with evidence from Ritchie and colleagues (2010). Some included the lack of time, variable levels of confidence in implementing ECEfES as well as differences in the value families place on ECEfES. Charlotte stated:

\begin{abstract}
I know the idea is to make it an integral part of your program, so its not just a special activity. But sometimes, you need to formally sit down and plan an experience that will help the children to kind of understand why you are doing something ... and I often find that there's just not enough time to do that, because other things happen, you're planning for other things.
\end{abstract}

The educators recognised solutions that had helped them overcome barriers, such as sharing common values around ECEfES, acknowledging differences in the understanding and strengths of each educator, consistent communication, along with planning and prioritising specific ECEfES goals and experiences.

Within our QIP this year, we're trying to acknowledge different educators' strengths, and they have goals set within that and they're relating to sustainability. So we're really being mindful of that and trying to grow people ... all our staff in that way and looking at the things that they feel comfortable with (Ashley). 


\section{The voices of young children}

Through this study, it became clear that the notion of children as environmental actors resonated with the participating educators. The educators' beliefs about children and their practices were underpinned by contemporary and reconceptualised images of children as competent, capable and active participants, shaped by their sociocultural contexts. An approach that was central to the practice of educators in this study was acknowledging children's voices. Their program was based on interests that children displayed, as well as questions or concerns children had raised. Although it was mentioned that some families do not necessarily understand the value of ECEfES, many children had actually constructed knowledge about sustainable practices from their families and shared this with educators and peers. Charlotte shared an example of a discussion with a parent: 'Look, Will has a great understanding of that, do you talk about that at home?' In turn, the children's expertise was shared with families, resulting in a recurring process of interaction and learning between educators, children and their families.

Involving children in collaborative projects was central to the participating educators' practice, emphasising both the educators' understanding of the NQF documents and consideration of the social construction of children's knowledge. Sociocultural theory illuminates the necessity of organising experiences in ECEC that allow for maximum interaction and communication between educators, children and their peers (Pramling Samuelsson, 2011). Knowing this, the educators in this study indicated they had facilitated childinitiated collaborative projects where children engaged in sophisticated thinking about complex environmental issues. This supports literature that recognises children are indeed capable of this (Edwards \& Cutter-Mackenzie, 2011; Elliott \& Young, 2016; Palmer \& Suggate, 2004). Charlotte viewed it as 'empowering them to be part of the process'. There was an emphasis on encouraging participation in problem solving, decision making and focusing on real life issues of relevance and importance to the children, building on their prior experience and knowledge. 'We want thinking children, not just children who are just told what to do' (Ashley). A number of collaborative projects were described by the educators, which were aimed at reconnecting children to the life sustaining processes from which humans have become alienated. This included projects involving origins of food and resources, worm farms, composting, shared gardens, conservation and waste disposal. This approach empowers children to think critically about why we need to live sustainably, supporting them to make sense of complex environmental issues of interest and relevance to their sociocultural context, and become active agents of change (Davis \& Elliott, 2014; Reunamo, 2007).

The findings showed that a cyclical process of interaction and learning between educators, children and their families took place. Families have provided the educators with feedback in relation to their children's environmentally responsible practices at home and in the community. The educators reported that children have been going home and having conversations with their families about sustainability issues, such as waste. Charlotte affirmed this:

When they use the paper towel in there (the bathroom), I often just say to them to use one, because they really don't need to just keep pulling them out, because they're wasting paper. One of the children went home ... they were out somewhere and said, 'Mum, you're only allowed to use one!' That type of thing, they actually do listen here and they do take it home.

The educators' sustainability messages were reaching families, with children as active catalysts for change (Davis \& Elliott, 2014; Reunamo, 2007).

\section{A 'whole-of-settings' approach involving families and the community}

The educators' belief in the importance of collaborating with families when attempting to embed ECEfES practice was reiterated in the findings from the analysis of the NQF documents. Guidance was provided for engaging the support of families and the community in embedding ECEfES, as well as explaining their sustainable practices to families. When asked a question about collaboration, Denise highlighted that sometimes, families are unwilling to engage in decision making around ECEfES, or do not have the time, but for other families, it is very important to them: It just goes back to knowing your families and knowing what level that they're comfortable sharing and being involved and then going from there'. Ashley reflected on how the EYLF document has supported them to engage families:

With the EYLF, they've given you lots of words to be able to explain that [ECEfES] more to families. I think it (the EYLF) has made you have a look and really explain what you are doing to families so they understand why you're doing things a lot more.

Ashley mentioned they justify their ECEfES planning with EYLF quotes in parent meetings.

Engaging families in a 'whole-of-settings' approach ensured the centre's ECEfES program was relevant to the sociocultural contexts within the setting, enhancing the potential for sustainable change. Involving families in the process of becoming more sustainable, as well as basing the program on the contributions of children and families, or happenings within the community, provided a sense of authenticity and relevance to all involved:

It's authentic because what we're doing is based on that. It's not something we've decided is a good idea just because. The children then value it a lot more and the families value what we do because they know that we're listening to them (Charlotte).

The educators recognised their role in promoting environmentally responsible behaviour in children, but also in supporting families to embed relevant practices and knowledge 
at home as well. The collaboration between children, families, educators and the wider community is essential to support the central tenets of sociocultural theory (Cutter-Mackenzie \& Edwards 2006). This has supported the educators to negotiate priorities for action based on the sociocultural contexts of families and the community, arranging ECEfES programs that are tailored to these contexts. The focus on children's construction of knowledge through active participation and exploration of their environment reflects a core element of sociocultural theory and was demonstrated as important to the educators within this centre through their daily practices.

While a 'whole-of-settings' approach promotes a collective awareness of the importance of living sustainably, in this study it also supported ECEfES connections across generations. Charlotte reflected on a child's experience in the centre's garden during Families Week:

Sam showed her grandparents the garden and she was telling them that her father had set it up. And then she and Lucy picked some beans, which they then shared with their grandparents for morning tea.

Here, a child shared her culturally-valued knowledge about the garden with her grandparents, which from a sociocultural lens, she had constructed through collaboration with educators, peers and families. The child appeared to feel a sense of ownership and responsibility as her father helped her and her peers to build the garden. She was then able to share her sustainability knowledge, as well as the product of combined efforts, with her grandparents. This permeation of sustainability knowledge and skills within the homes of families is evidence that 'whole-of-settings' approaches, which take into account sociocultural contexts, are essential to ECEfES in ECEC centres.

\section{Engaging in reflection}

The introduction of the NOF supported the educators to reflect more deeply on their ECEfES practices, enabling them to formulate goals based on areas that need improvement. They have devised several ECEfES goals within their QIP. Denise stated, 'That [QIP] certainly makes you look at those practices more and I think the more you look at it and do reflective practice, the more you continue on that journey'. Furthermore, the educators placed emphasis on reflecting on their own socio-culturally constructed understandings of ECEfES and actively seeking supporting resources to foster a stronger and cohesive understanding. They spoke of engagement with a broad range of professionals at conferences and events. An example is the NSW Early Childhood Environmental Education Network (ECEEN), an organisation aiming to create living and learning spaces within communities, which reflect on and inspire sustainable practices (NSW ECEEN, 2014). The NSW ECEEN ECO SMART Early Childhood Checklist (NSW ECEEN 2014) was a useful tool for reflecting on practice and identifying opportunities to implement sustainable practices across the seven NQS quality areas. Being part of a large organisation that values ECEfES, the educators had access to a multitude of training and resources. This highlights the need for and benefits of training focusing specifically on the ECEfES requirements across the NQF.

The educators took the practice of reflection further by encouraging families, the community and educators to reflect upon their own early childhood experiences and connections with the natural environment. This allowed for deeper reflection, not only about the influences on their own knowledge and practices, but also the significance of this approach in embedding strong foundations of knowledge and practices in children. Ashley elaborated on her childhood experience practising sustainable stewardship on her family's farm. Living sustainably and in harmony with nature was crucial to her family's survival:

\section{I grew up thinking really carefully about resources and we had to be very careful or we'd run out of water in drought times. We wouldn't have food if we didn't plan and think (about how) we had to follow the seasons and the cycles and plan accordingly. So for me that would have been in my practice. I've definitely always had that thinking and I'm grateful to the background that I've had that's given me that.}

Reflecting on these memories, Ashley recognised these early childhood experiences had impacted on her behaviours and had provided lifelong learning, which consequently informed her own educational philosophy and practices. Her statement encompasses just how meaningful ECEfES can be in children's lives.

\section{Recommendations}

A number of recommendations arise from this study that could support ECEC educators to meet the ECEfES requirements of the NOF. Firstly, it is recommended that educators wishing to embed ECEfES programs need to collaborate, not only with children but also their families. Such collaboration can lead to the creation of authentic sustainable changes within dynamic sociocultural contexts. In the spirit of collaboration, it is recommended educators support families to see the value of ECEfES by encouraging families to reflect on their own early childhood experiences with, and connections to, the natural environment. A permanent ECEfES section in the centre's 'daily reflection' for families could be established. This would support families to understand ECEfES is valuable learning for children and ensure ECEfES becomes embedded in day-to-day practices.

Another recommendation for practice is to involve children in the ECEfES process. It is vital that educators continuously reconceptualise their understandings of children as contemporary research emerges and moves away from out dated misconceptions about children's abilities. Both the NQS and EYLF reflect this view of children as social beings, problem solvers, critical thinkers and agents of change, and these documents advocate for transformative pedagogies that empower children to be active participants within the community. 
Finally, it is recommended that educators continually reflect on whether their ECEfES practices are meeting the requirements of the NQF. Educators can remain aspirational and gain further understanding about ECEfES by engaging with a broad range of professionals. Linking in with NSW ECEEN had particularly benefited the educators in this study. Tools such as the NSW ECEEN ECO SMART Early Childhood Checklist can be useful for reflecting on practice and identifying opportunities to implement practical sustainable practices across the seven NQS quality areas (NSW ECEEN, 2014). The need for, and benefits of training focusing specifically on the NOF ECEfES requirements in ECEC centres is also emphasised.

\section{Limitations}

The researcher cannot conclude the experiences of participants in this setting are representative of educators within the wider ECEC population. This study did not include educators from centres who are struggling to understand the meaning of ECEfES, like those identified in previous research (Davis, 2008; Elliott \& Davis, 2009; Ritchie et al., 2010). Also, this study focused primarily on the perceptions of the educators and did not involve children's voices directly in the data.

\section{Conclusion}

The value of ECEC as a platform for lifelong learning and its role in generating social and cultural change for a sustainable future is widely sanctioned (Davis \& Elliott, 2014; Davis et al., 2009; Pramling Samuelsson \& Kaga, 2008). As a consequence of the introduction of the NOF, educators in Australia have experienced significant changes (Council of Australian Governments, 2009), particularly in regard to the ECEfES requirements within the NQS and EYLF.

This current research project has contributed to the existing body of knowledge regarding ECEfES, and how educators work toward meeting the ECEfES related requirements of the NOF in Australia. There are a number of challenges encountered by ECEC educators as they attempt to bring young children to a greater level of responsibility for the environment. Lack of time and ECEfES understanding can potentially hinder progress. Reflecting on practices and prioritising ECEfES goals, combined with consistent communication and respect for differences in ECEfES understandings, are key factors that contribute to overcoming these barriers.

Educators in this study focused on ECEfES prior to the introduction of the NQF, however, the introduction of the NQF supported these educators to enhance their ECEfES practices, including a 'whole-of-setting' approach, where collaboration with children, families and the community, is essential.

The NOF has furthered educators' reflection on their practice and confirmed their view of children as competent and socio-culturally constructed beings, capable of contributing to a sustainable future. The provision of high-quality ECEfES programs has the power to permeate sustainable behaviours into family life outside the ECEC setting, with children as active agents of change. These findings illuminate the crucial role and responsibilities of ECEC educators in supporting children to become environmentally responsible and contribute to a sustainable future.

\section{References}

Australian Children's Education and Care Quality Authority (ACECQA). (2011). Education and Care Services National Regulations. Retrieved from www.legislation.nsw.gov.au/\#/view/regulation/2011/653.

Australian Children's Education and Care Quality Authority (ACECQA). (2013). Guide to the National Quality Standard. Retrieved from www. acecqa.gov.au/national-quality-framework/the-national-quality-standard.

Bentley, D. (2013). 'I think they all felt distressed!': Talking about complex issues in early childhood. Childhood Education, 89(1), 9-14. http://dx.doi. org/10.1080/00094056.2013.757179

Bowen, G. A. (2009). Document analysis as a qualitative research method. Qualitative Research Journal, 9(2), 27-40. http://dx.doi. org/10.3316/QRJ0902027

Braun, V., \& Clarke, V. (2006). Using thematic analysis in psychology. Qualitative Research in Psychology, 3(2), 77-101. http://dx.doi. org/10.1191/1478088706qp063oa

Chan, B., Choy, G., \& Lee, A. (2009). Harmony as the basis for education for sustainable development: A case example of Yew Chung international schools. International Journal for Early Childhood, 41(2), 35-48. http:// dx.doi.org/10.1007/BF03168877

Chawla, L., \& Cushing, D. F. (2007). Education for strategic environmental behavior. Environmental Education Research, 13(4), 437-452. http:// dx.doi.org/10.1080/13504620701581539

Commonwealth of Australia Department of Climate Change and Energy Efficiency. (2011). Australian Climate Commission Report: The Critical Decade. Retrieved from www.climatecouncil.org.au/uploads/34ab075 fb66ce1b08976ed1505bec7a3.pdf.

Council of Australian Governments. (2009). National partnership agreement on the national quality agenda for early childhood education and care, Commonwealth of Australia. Canberra, ACT: Retrieved from http://files.acecqa.gov.au/files/NOF/nap_national_quality_agenda_early_ childhood_education_care_signature.pdf.

Cutter-Mackenzie, A., \& Edwards, S. (2006). Everyday environmental education experiences: The role of content in early childhood education. Australian Journal of Environmental Education, 22(2), 13-19. http://dx.doi.org/10.1017/aee.2014.37

Davis, J. (2005). Educating for sustainability in the early years: Creating cultural change in a child care setting. Australian Journal of Environmental Education, 21(1), 47-55. http://dx.doi.org/10.1017/S081406260000094X

Davis, J. (2008). What might education for sustainability look like in early childhood? In I. Pramling Samuelsson, Y. Kaga (Eds.), The contribution of early childhood education to a sustainable society (pp. 18-24). Paris, France: UNESCO. Retrieved from unesdoc.unesco.org/ images/0015/001593/159355E.pdf.

Davis, J., \& Elliott, S (Eds.). (2014). Research in early childhood education for sustainability: International perspectives and provocations. Milton Park, NSW: Routledge.

Davis, J., Engdahl, I., Otieno, L., Pramling-Samuelsson, I., Siraj-Blatchford, J., \& Vallabh, P. (2009). Early childhood education for sustainability: Recommendations for development. International Journal of Early Childhood, 41(2), 113-117. http://dx.doi.org/10.1007/BF03168882

Department of Education, Employment and Workplace Relations (DEEWR). (2009). Belonging, Being \& Becoming: The Early Years Learning Framework for Australia. Canberra, ACT: Commonwealth of Australia. 
Domka, L. (2004). Environmental education at preschool. International Research in Geographical and Environmental Education, 13(3), 258-263. http://dx.doi.org/10.1080/10382040408668520

Dymenta, J., Davisb, J., Nailona, D., Emerya, S., Geteneta, S., McCreac, N., \& Hilla, A. (2014). The impact of professional development on early childhood educators' confidence, understanding and knowledge of education for sustainability. Environmental Education Research, 20(5), 660-679. http://dx.doi.org/10.1080/13504622.2013.833591

Edwards, S. (2009). Early childhood education care: A sociocultural approach. Castle Hill, NSW: Pademelon Press.

Edwards, S., \& Cutter-Mackenzie, A. (2011). Environmentalising early childhood education curriculum through pedagogies of play. Australasian Journal of Early Childhood, 36(1), 51-59.

Edwards, S., Fleer, M., \& Nuttall, J. (2008). A research paper to inform the development of an Early Years Learning Framework for Australia. Melbourne, Vic.: Office for Children and Early Childhood Development Department of Education and Early Childhood Development. Retrieved from docs.education.gov.au/documents/research-paper-informdevelopment-early-years-learning-framework-australia.

Elliott, S. (2014). Early childhood education for sustainability and natural outdoor playspaces, Researching change and theorizing about interfaces. In J. Davis \& S. Elliott, (Eds.), Research in Early Childhood Education for Sustainability, International perspectives and provocations, (pp. 127-142). Milton Park, NSW: Routledge.

Elliott, S., \& Davis, J. (2009). Exploring the resistance: An Australian perspective on educating for sustainability in early childhood. International Journal of Early Childhood, 41(2), 65-77. http://dx.doi.org/10.1007/BF03168879

Elliott, S., \& Young, T. (2016). Submission for the AJEE special issue for the 18th biennial AAEE conference-sustainability: Smart strategies for the 21st century. Nature by default in early childhood education for Sustainability. Australian Journal of Environmental Education, 32(1), 57-64. http://dx.doi.org/10.1017/aee.2015.44

Fleer, M., \& Richardson, C. (2004). Observing \& planning in early childhood settings: Using a sociocultural approach. Canberra, ACT: Early Childhood Australia.

Green, S. S. (2013). Preschool teachers' early perceptions of education for sustainable development in early childhood education (Masters thesis). Southern Illinois University, Carbondale, IL, USA.

Inoue, M., O'Gorman, L., \& Davis, J. (2016). Investigating early childhood teachers' understandings of and practices in education for sustainability in Queensland: A Japan-Australia research collaboration. Australian Journal of Environmental Education, 32(2), 174-191. http:// dx.doi.org/10.1017/aee.2016.4

Ji, O., \& Stuhmcke, S. (2014). The Project Approach in early childhood education for sustainability: Exemplars from Korea and Australia. In J. Davis \& S. Elliott (Eds.), Research in early childhood education for sustainability, international perspectives and provocations (pp. 158-179). Milton Park, NSW: Routledge.

Lewis, E., Mansfield, C., \& Baudains, C. (2010). Going on a turtle egg hunt and other adventures: Education for sustainability in early childhood. Australasian Journal of Early Childhood, 35(4), 95-100. Retrieved from www.earlychildhoodaustralia.org.au/wp-content/ uploads/2014/06/AJEC1004.pdf

NSW ECEEN Early Childhood Environmental Education Network (ECEEN). (2014). ECO SMART for early childhood: A sustainability filter for Quality Improvement Plans. St Pauls, NSW: NSW ECEEN. Retrieved from www.eceen.org.au.

Palmer, J., \& Suggate, J. (2004). The development of children's understanding of distant places and environmental issues: Report of a UK longitudinal study of the development of ideas between the ages of 4 and 10 years. Research Papers in Education, 19(2), 205-237. http://dx.doi.org/10.1080/02671520410001695434
Pollock, K. (2014). Uncovering what lies between theory and practice: An overview of a case study into the experiences of educators as they attempted to inspire preschool children to become environmentally responsible, through the implementation of the National Quality Framework (Unpublished honours thesis). University of Wollongong, Wollongong, NSW, Australia.

Pramling Samuelsson, I. (2011). Why we should begin early with ESD: The role of early childhood education. International Journal of Early Childhood, 43(2), 103-118. http://dx.doi.org/10.1007/s13158011-0034-x

Pramling Samuelsson, I., \& Kaga, Y. (Eds.). (2008). The contribution of early childhood education to a sustainable society. Paris, France: UNESCO. Retrieved from unesdoc.unesco.org/ images/0015/001593/159355E.pdf.

Reunamo, J. (2007). The agentive role of children's views in sustainable education. Journal of Teacher Education for Sustainability, 8(1), 68-79. http://dx.doi.org/10.2478/v10099-009-0014-5

Ritchie, J., Duhn, I., Rau, C., \& Craw, J. (2010). Titiro Whakamuri, Hoki Whakamua. We are the future, the present and the past: Caring for self, others and the environment in early years' teaching and learning. Wellington, New Zealand: Teaching \& Learning Research Initiative.

Salonen, A.O., \& Tast, S. (2013) Finnish early childhood educators and sustainable development. Journal of sustainable Development, 6(2), 70-85. http://dx.doi.org//10.5539/jsd.v6n2p70

Siraj-Blatchford, J. (2009). Editorial: Education for sustainable development in early childhood. International Journal of Early Childhood, 41(2), 9-22. http://dx.doi.org/10.1007/BF03168875

Siraj-Blatchford, J., Smith, K., \& Pramling Samuelsson, I. (2010). Education for sustainable development in the early years. Organisation Mondiale Pourl Education Prescolaire (OMEP). Retrieved from www.327matters.org/Docs/ESD\%20Book\%20Master.pdf.

Stake, R. E. (1995). The art of case study research. Thousand Oaks, CA: Sage Publications, Inc.

Stonehouse, A. (2002). NSW curriculum framework for children's services, the practice of relationships, essential provisions for children's services. Sydney, NSW: NSW Department of Community Services, Office of Childcare.

Stuhmcke, S. M. (2012). Children as change agents for sustainability: An action research case study in a kindergarten (Unpublished thesis). University of Technology, Brisbane, Qld, Australia.

Tilbury, D. (2013). Foreword. In J. Davis, S. Elliott (Eds.), Research in early childhood education for sustainability. International perspectives and provocations (pp. xv-xvi). Milton Park, NSW: Routledge.

United Nations Educational, Scientific and Cultural Organisation (UNESCO). (2012). Education for sustainable development good practices in early childhood. Retrieved from unesdoc.unesco.org/ images/0021/002174/217413e.pdf.

United Nations Environment Program. (2015). The Emissions Gap Report 2015. Retrieved from uneplive.unep.org/media/docs/theme/13/ EGR_2015_301115_lores.pdf.

United Nations International Children's Emergency Fund (UNICEF). (1989). United Nations Convention on the Rights of the Child. Retrieved from www.unicef.org/crc/.

Vaealiki, S., \& Mackey, G. (2008). Ripples of action: Strengthening environmental competency in an early childhood centre. Early Childhood Folio, 12(2008), 7-11. Retrieved from www.nzcer.org.nz/ system/files/ECFolio_12_2008_007.pdf.

Vygotsky, L. (1978). Mind in society: The development of higher psychological processes. Cambridge, MA: Harvard University Press.

Yin, R. K. (1984). Case study research. Beverly Hills, CA: Sage Publications, Inc. 
Copyright of Australasian Journal of Early Childhood is the property of Early Childhood Australia and its content may not be copied or emailed to multiple sites or posted to a listserv without the copyright holder's express written permission. However, users may print, download, or email articles for individual use. 